\title{
KAMAR MANDI SEBAGAI TEMPAT BERSUCI (THAHARAH)
}

\author{
Agung Sedayu \\ Teknik Arsitektur UIN Maulana Malik Ibrahim Malang, Email: \\ agung_resta@yahoo.co.id. Telp: 08155172619
}

\begin{abstract}
Keeping cleanliness and holiness is the duty for all moslems. To perform these religious duties, every time and everywhere, we must keep and support hard on the holiness of the physic and psychic value aspects. Most cleaning activities have been done in toilet and the other similar places. The Main tool to clean is water; therefore toilet is always having water having the image as a wet place. Toilet is one of the arranged rooms in building and assumed to be added room that is not so important. In fact, it has a very vital and important function. Inside of the toilet we have the erudition and philosophy which must be done, like praying before and after entering this room, and also some other rules to follow when we are in it. Cleaning the psychic is started at cleaning the body, and cleaning the psychic is supported by cleanliness of our environment including toilet as a part of the house. Therefore, before designing it, all of the moslem architects must concern and focus on the erudition and philosophy of Islamic fiqih containing about the effort to be clean and holy. Design results should reflect Islamic values, and the toilet having Islamic characteristics, especially having strength points on cleanliness and holiness. This paper is to discuss about toilet design from the perspective of fiqih values on cleanliness and holiness. The objectives are to give more information and knowledge about toilet design principles having Islamic values based on fiqih law references on cleanliness and holiness.
\end{abstract}

\section{Keywords: Toilet, Place To Clean}

\begin{abstract}
Abstraksi
Menjaga kesucian dan kebersihan adalah kewajiban bagi seluruh umat Islam. Untuk melaksanakan kewajiban agama tersebut, kapanpun dan dimanapun kita harus menjaga dan mendukung kesucian badan dan nilai kebersihan badan. Sebagian besar aktivitas bersihbersih (baca bersuci) di lakukan di kamar mandi atau di tempat-tempat sejenisnya. Alat utama yang di gunakan untuk bersuci adalah air, oleh karena itu toilet mempunyai image sebagai tempat yang (selalu) basah. Kamar mandi adalah salah satu bangunan yang berada di dalam bangunan dan di asumsikan sebagai ruang tambahan yang tidak seberapa penting. Pada kenyataannya , kamar mandi/kamar mandi mempunyai fungsi yang sangat penting. Di dalam kamar mandi ada ilmu dan falsafah tersendiri yang harus dilakukan, seperti berdo'a sebelum dan sesudah masuk ruangan tersebut dan beberapa etika dan aturan yang harus di jalani ketika berada di dalamnya. Kebersihan fisik di mulai dari kebersihan badan, dan kebersihan fisik di dukung oleh kebersihan lingkunga, termasuk kebersihan toilet sebagai bagian dari bangunan yang berada di dalam rumah. Oleh karena itu sebelum mendesain bangunan kamar mandi, para arsitek muslim harus konsentrasi dan fokus kepada aspek kebersihan dan kesucian. Hasil merefleksikan nilai-nilai keislaman dan juga mempunyai karakteristik keislaman, khususnya pada nilai kebersihan dan kesucian. Makalah ini membahas nilai kebersihan dan kesucian. tujuannya adalah untuk memberikan informasi dan pengetahuan tentang prinsip-prinsip desain kamar mandi yang islami berdasarkan hukum fikih terhadap kebersihan dan kesucian.
\end{abstract}

\section{Kata Kunci: Kamar Mandi, Tempat untuk Bersuci}




\section{Pendahuluan}

Untuk melakukan aktivitas mandi dan buang hajat diperlukan desain dan rancangan Kamar Mandi dan WC yang asri dan bersih. Keperluan mencuci barang perabot dapur, pakaian atau furnitur rumah akan membutuhkan tempat mencuci yang bersih dan nyaman pula. Sedangkan untuk keperluan berwudhu membutuhkan ruang (space) untuk wudhu yang cukup nyaman, terjaga kesucian, dan terletak jauh dari tempat yang kotor. Dalam kegiatan thaharah itu sendiri terdapat pembedaan fungsi, yakni thaharah untuk ibadah seperti wudhu dan mandi besar, mandi sebagai rutinitas sehari-hari, buang hajat baik besar maupun kecil, dan mencuci alat dapur, pakaian, dan barang lain (Hazm, 2007: 11). Pembedaan fungsi ini dijadikan pertimbangan dalam perancangan Kamar Mandi, tempat cuci, dan WC. Perlu ada pembedaan ruang (space) agar najis atau kotoran yang ada tidak bercampur baur. Rancangan yang dibawa para nenek moyang kita dalam arsitektur tradisional nusantara sejak dulu sudah menerapkan dan mempertimbangkan pembedaan ruang dan fungsi tersebut. Mereka merancang Kamar Mandi diletakkan agak jauh dari tempat tinggal yang dijaga kebersihan dan kesuciannya. Bahkan letaknya ditempatkan berdekatan dengan sumur, gudang, dan kandang hewan peliharaan. Sampai sekarang pun tatanan seperti ini masih nampak di rumah-rumah pedesaan atau pelosok daerah. Sementara di daerah perkotaan sudah menempatkan Kamar Mandi sebagai komoditas yang perlu diperuntukkan dan dipamerkan kepada orang lain. Sebagaimana pada Gambar $1-4$ di bawah tentang model-model Kamar Mandi dan WC.

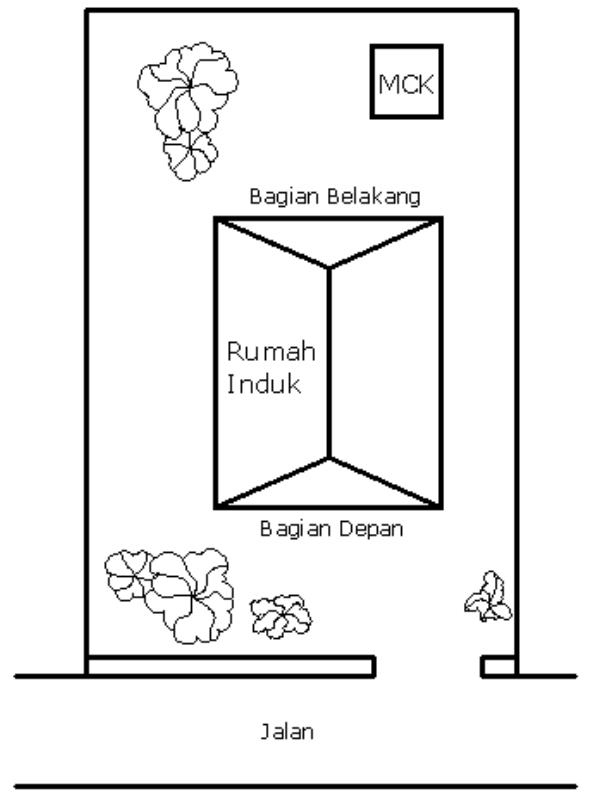

Gambar 1. Letak tempat MCK di bagian belakang rumah

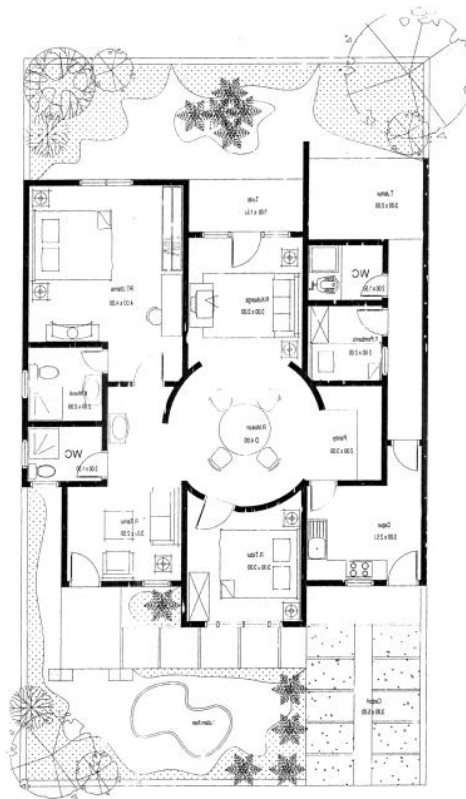

Gambar 2. Letak kamar mandi/WC di bagian dalam rumah modern 


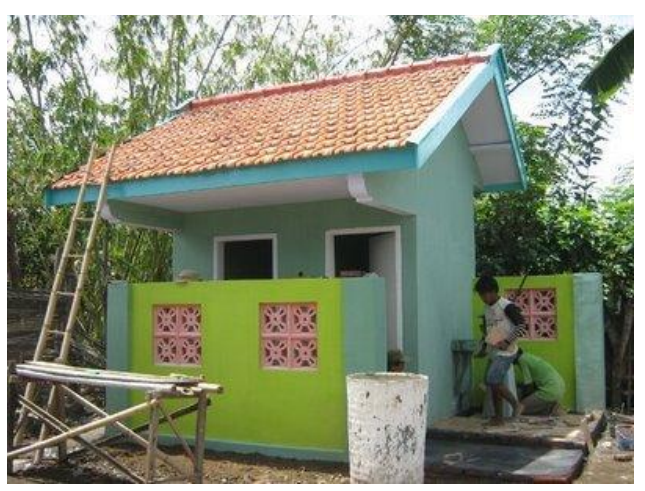

Gambar 3. KM/WC ini terletak pada bagian belakang rumah yang dirawat dan ditata bersih

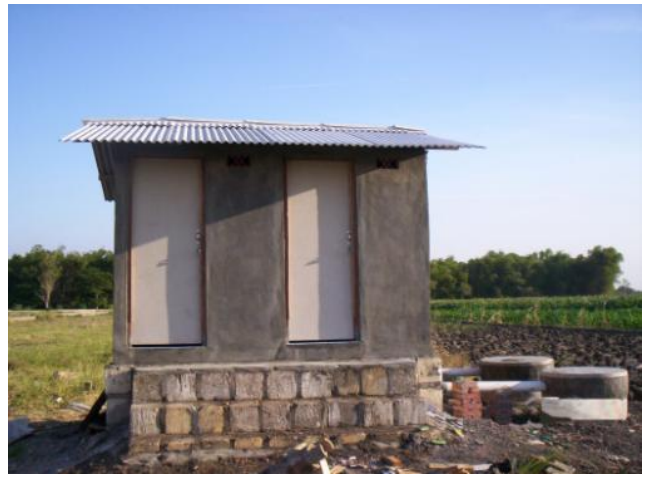

Gambar 4. KM/WC ini relatif bersih walau sederhana khusus untuk para petani umum (komunal)

\section{Kajian dan Penelitian Terdahulu}

Beberapa penelitian dan kajian yang telah dilakukan sebelumnya tentang toilet atau kamar mandi dan komponen-komponennya antara lain adalah :

\section{Titien Woro Murtini (1995)}

Penelitian ini dilakukan oleh Ir. Titien Woro Murtini, MSA. dan kawan-kawan pada tahun 1995 dengan judul Kajian Perancangan Kamar Mandi Rumah Tinggal. Penelitian fokus pada aspek perubahan perancangan Kamar Mandi rumah tinggal yang dipengaruhi oleh kemajuan industri. Lokasi penelitian adalah rumah tinggal di komplek PERUMNAS Banyumanik Semarang, dengan responden pemilik yang memperoleh rumahnya secara KPR. Hasil penelitian ini menyebutkan bahwa terjadinya perubahan perancangan fisik kamar mandi yang dipengaruhi oleh : peningkatan kualitas, peningkatan kuantitas, peningkatan kapasitas, dan perwujudan perilaku penghuni terhadap rumah tinggalnya yang menyangkut aspek persepsi, privasi, serta aktualisasi diri. Rekomendasi dari penelitian ini hendaknya perubahan di atas perlu disesuaikan dengan kondisi denah rumah, sehingga persyaratan untuk rumah sehat dan persyaratan teknis tetap dapat dicapai, oleh sebab itu diperlukan pemantauan dari pihak yang berwenang dalam hal ini Dinas Tata Kota khususnya bidang Tata Bangunan untuk memberikan penyuluhan dan pemantauan terhadap perubahan rumah tinggal terutama dalam pendaftaran Izin Mendirikan Bangunan (IMB) bagi masyarakat.

\section{Prima Nataniel Ambeno (2010)}

Penelitian ini dilakukan oleh Prima Nataniel Ambeno pada tahun 2010 dengan judul Desain Sarana MCK untuk Daerah Korban Bencana. Deskripsi isi penelitian ini bahwa Indonesia dilihat dari letak geografisnya merupakan daerah yang berpotensial terkena 
bencana alam. Sumber Pusat Data dan Informasi Pusat Penanggulangan Krisis, Departemen Kesehatan menyebutkan Indonesia per September 2009 telah mengalami sebanyak 920 kejadian bencana. Menanggapi hal tersebut, maka diperlukan upaya cepat tangga pemerintah. Upaya cepat tanggap yang dapat dilakukan pemerintah adalah mengevakuasi korban dan memfasilitasi segala kebutuhan korban bencana seperti fasilitas MCK. Untuk meminimalisasi penyakit yang disebabkan kurang terjaganya kebersihan seperti diare, ISPA dan lainnya, maka dibutuhkan fasilitas MCK yang nantinya akan digunakan oleh pengungsi dalam kesehariaanya untuk menjaga kebersihan tubuhnya. Dalam fakta di lapangan, biasanya suatu tempat pengungsian fasilitas MCK kurang dapat memenuhi kebutuhan pengguna. Desain MCK untuk daerah bencana ini merupakan pengembangan desain dan konsep baru dari MCK untuk daerah bencana, dengan tujuan utama untuk dapat lebih memenuhi kebutuhan para pengungsi akan suatu sarana MCK dan operator MCK dalam perakitannya. Dalam perancangan MCK ini, pendekatan kebutuhan terhadap instalasi dan perawatan MCK serta penggunaan MCK untuk sarana kebersihan di kegiatan lain dijadikan sebagai konsep awal, yaitu smart, sedangkan pendekatan pengguna untuk dapat memberikan memberikan kesan baru terhadap sarana MCK di daerah bencana, yaitu new image. Selain juga dilakukan pendekatan terhadap kebutuhan material yaitu eco friendly.

\section{Hermawan (2010)}

Penelitian ini berjudul Desain Closet Jongkok Yang Memperhatikan Kebutuhan Konsumen dan Dilandasi Nilai - Nilai Islam Dalam Pemakaiannya, dilakukan oleh Hermawan pada tahun 2010. Dengan dilatarbelakangi populasi penduduk Indonesia yang beragam Islam lebih besar, dari 205.843 juta jiwa adalah Islam 87.9\%, Kristen 5.7\%, Katolik 3.3\%, Hindu 1.8\%, Budha $1.1 \%$ dan lainnya $0.2 \%$. populasi muslim di Indonesia merupakan pasar terbesar bagi produk tertentu, tak terkecuali closet. Mengapa closet? Closet adalah kebutuhan primer saat ini dan semua rumah hampir pasti memiliki sebuah closet yang terpasang dalam rumahnya. Muhammad SAW memberi kita contoh, tata cara membuang hajat yang terekam lewat kitab Ihya' Ulumiddin'. Kenyataannya adalah justru umat Islam kini jauh dari tuntunan Islam sendiri, khususnya dalam hal adab buang hajat. Melihat closet-closet yanga da di pasaran tidak mendukung pelaksanaan adab buang hajat secara Islami, penulis berinisiatif untuk meredesain closet. Langkah pertama yang dilakukan adalah mencari landasan penjelas tentang tata cara buang hajat yang Islami, dari penjelasan tersebut (kumpulan hadist, kitab Ihya' Ulumiddin) kita pilah-pilah dengan definisi : Merupakan aktivitas hubungan manusia-Allah yang berkaitan erat dengan doa 
dan pengaturan arah, dan merupakan aktivitas manusia dengan faktor pendunkung buang hajat, dalam hal ini closet adalah salah satu pendukungnya. Dari poin kedua maka segera ditelaah bagaimana supaya aktivitas manusia-closet bisa disesuaikan dengan tuntunan Islam. Kesimpulan yang didapat adalah menghindari atau meminimalisasi percikan air najis (air seni dan air kotor dari closet) dan dalam jongkoknya ditumpukan dalam kaki kiri. Langkah kedua adalah mengetahui keinginan konsumen tentang gambaran closet yang ideal bagi mereka. Dengan menyebar kuesioner sebanyak 30 responden diharapkan $90 \%$ keinginan konsumen bisa diketahui. Keinginan konsumen itu antara lain: closet jongkok nyaman dan terbiasa digunakan, closet jongkok mudah dibersihkan, closet jongkok baik untuk kesehatan, closet jongkok sederhana dan mudah dipasang, closet jongkok didesain bervariatif dan artistik. Langkah selanjutnya adalah menggali kelemahan dan kelebihan dari closet pembanding, dalam hal ini closet jongkok diwakili oleh merek Ina, sedangkan coset duduk diwakili oleh merek Toto. Setelah semua terdefinisi (faktor pemenuhan kaidah Islamiah, kebutuhan konsumen dan perbandinagn produk) maka dibuat desain-desain konsepnya. Pemilihan konsep didasarkan pada pertemuan keinginan konsumen dan desainer, sehingga didapatkan nilai tengah dari konsep diatas. Desain baru diharapkan memiliki nilai plus yaitu memenuhi nilai-nilai Islam, kebutuhan konsumen dan lebih bagus dari produk pembanding.

Dari tiga penelitian tersebut bahwa perubahan perancangan kamar mandi atau toilet banyak dipengaruhi oleh faktor perilaku pengguna, namun perubahan itu hendaknya mempertimbangkan aspek kesehatan, kenyamanan, dan desain ruang yang lain. Kamar Mandi sebagai tempat membersihkan diri dan buang kotoran sangat rentan terhadap penyakit dan berkesan kotor. MCK umum dan toilet untuk korban bencana yang bersifat sementara dan darurat sangat mudah kotor dan berpeluang besar terhadap penyakit, sehingga perlu banyak faktor pertimbangan perancangan. Landasan filosofi islam dapat digunakan sebagai acuan mendasar dalam perancangan toilet secara keseluruhan yang mencakup segala komponennya, sehingga rancangan Kamar Mandi selain bersih, sehat, nyaman, estetis, juga sesuai hukum islam dan mendukung aktivitas ibadah agama.

\section{Tentang Thaharah}

Aktivitas thaharah atau bersuci berkaitan langsung dengan tempat mandi, cuci, dan kakus. Jadi perancangan tempat MCK juga mempertimbangkan aspek filosofis tentang thaharah, yang berkaitan pula secara langsung dengan air sebagai media dalam 
mensucikan diri. Menurut bahasa, Thaharah berarti annzhaafah wannazaahah minal ahdaats atau kurang lebih artinya bersih dan suci dari berbagai hadats. Menurut istilah fiqih ialah raf'ul hadats au izaalatun najas' yang berarti menghilangkan hadats atau membersihkan najis (Azhim, 2007: 8). Aktivitas Thaharah adalah kewajiban bagi setiap muslim di setiap saat, terutama ketika akan melakukan ibadah seperti shalat, baca al Quran, iktikaf, dan lain sebagainya, sebagaimana firman Allah SWT, "Kecuali orang-orang yang menghadap Allah dengan hati yang bersih" (QS asy Syu'araa': 89).

Dan firman Allah SWT, "Janganlah kamu bersembahyang dalam masjid itu selamalamanya. Sesungguhnya masjid yang didirikan atas dasar taqwa (masjid Quba), sejak hari pertama adalah lebih patut kamu sholat di dalamnya. Di dalam masjid itu ada orangorang yang ingin membersihkan diri. Dan sesungguhnya Allah menyukai orang-orang yang bersih" (QS at Taubah: 108).

Ditambahkan sabda Rasulullah SAW, "Dari Ibnu Umar ra. Ia berkata : 'Saya mendengar Nabi SAW bersabda, 'Tidak diterima shalat (yang dilaksanakan) tanpa bersuci (sebelumnya)" (Shahih Muslim).

Dari tiga keterangan di atas menegaskan bahwa Allah SWT sangat menyukai orang yang selalu berada dalam keadaan bersih, apalagi hendak beribadah kepada-Nya, persyaratan bersih ini mutlak wajib dipenuhi, sebab kalau tidak amal ibadah kita tidak akan diterima Allah SWT dan bernilai sia-sia. Masalah kebersihan atau kesucian ini adalah anjuran yang secara jelas telah disampaikan dalam al Quran dan sunnah. Hanya penerapannya masih kurang maksimal dan bersifat setengah-setengah. Keadaan suci atau bersih ini tidak hanya pada saat atau akan melakukan ibadah saja, namun di setiap waktu juga dianjurkan untuk selalu terbebas dari hadats baik besar maupun kecil. Cara untuk melakukan kebersihan adalah dengan berwudhu, mandi, siwak (menggosok gigi), mencuci pakaian, dan membersihkan tempat-tempat ibadah, rumah, dan lingkungan. Dengan menjaga kebersihan diri dan lingkungan sekitar akan terbebas dari segala jenis penyakit, gangguan polusi, dan akan terjamin kesehatannya.

\section{Kebersihan Diri dan Lingkungan}

Dukungan kebersihan lingkungan juga turut membantu proses kebersihan pribadi. Pribadi yang baik karena lingkungan yang baik, pribadi yang bersih salah satunya disebabkan lingkungan yang bersih pula. Kebersihan lahir salah satu penunjang kebersihan jiwa. Seperti ada motto mengatakan: Jiwa yang bersih terletak pada raga yang bersih, dan 
jiwa yang sehat terletak pada raga yang sehat', oleh karena itu kebersihan pangkal kesehatan, artinya dengan menjaga kebersihan akan tercapai kesehatan.

Kebersihan yang dianjurkan dan diwajibkan tidak hanya pada aspek fisik saja, namun hati kita juga perlu dibersihkan dan dibebaskan dari segala penyakit hati, seperti dengki, iri, sombong, takabur, kikir, dan lain-lain. Kebersihan dalam islam adalah kebersihan yang mencakup keseluruhan aspek baik lahir maupun batin. Anjuran untuk selalu membersihkan diri juga disampaikan Rasullullah SAW, sebagaimana beliau bersabda, "Sesungguhnya Allah baik dan menyukai kebaikan, bersih dan menyukai kebersihan, murah hati dan senang kepada kemurahan hati, dermawan dan senang kepada kedermawanan. Karena itu bersihkanlah halaman rumahmu dan jangan meniru-niru orang-orang Yahudi" (HR Tirmidzi).

Ditambahkan sabda Rasulullah SAW, "Siapa yang mengenakan pakaian hendaklah dengan yang bersih" (HR ath-Thahawi). Islam memiliki konsep yang mencakup secara keseluruhan tentang kebersihan. Berikut bagan mengenai kebersihan menurut konsepsi islam.

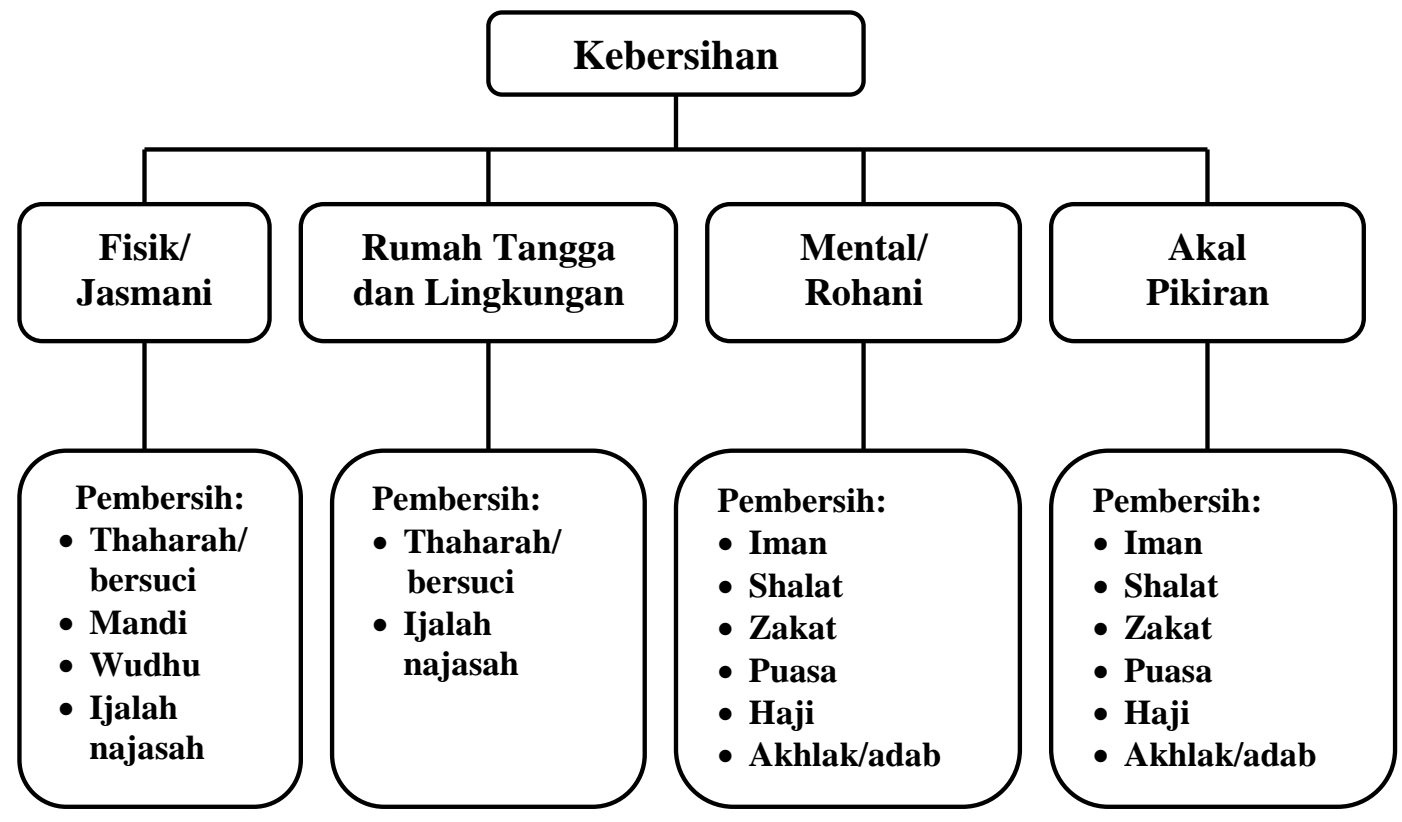

Gambar 4. Bagan konsep kebersihan menurut islam Sumber : Taufik, 2007: 12

Dari bagan di atas, dapat disimpulkan bahwa kebersihan tercakup dalam dua bagian, yakni lahir dan bathin. Untuk membersihkan bagian yang bersifat fisik atau lahir adalah dengan thararah atau bersuci, mandi, wudhu, mencuci, dan membersihkan najis. Sedangkan dalam bagian bathin adalah dengan memperkuat iman dan akhlak dengan cara 
ibadah shalat, puasa, zakat, haji, sabar, qanaah, zuhud, dan lain-lain yang bersifat terapi hati dan pikiran.

Kebersihan adalah pangkal kesehatan begitulah motto yang sering kita jumpai di berbagai tempat baik toilet, mushala, bahkan ruang kelas sekolah. Hadits yang berbunyi Kebersihan adalah sebagian dari iman juga terpampang di banyak tempat. Dari anjuran dan peringatan untuk selalu hidup bersih sudah sedemikian banyak baik dari agama islam maupun dari pihak atau sumber pengingat yang lain, namun dalam praktek kehidupan sehari-hari tidaklah demikian mudah diaplikasikan orang. Masih banyak kita lihat dan temui banyak kamar mandi dan WC yang jorok, bau, dan kotor, baik di gedung kantor, sekolah, tempat ibadah sekalipun seperti masjid dan mushalla juga kurang terjaga kebersihannya. Motto kebersihan di atas dampaknya bukan isapan jempol belaka, melainkan dapat menunjang meningkatkan keimanan dan kesehatan. Hal ini disampaikan oleh Rasulullah SAW, Mohonlah kepada Allah keselamatan dan afiat (kesehatan). Sesungguhnya tiada sesuatu pemberian Allah sesudah keyakinan (iman) lebih baik daripada kesehatan" (HR Ibnu Majah).

Hadits ini memberitahukan bahwa dua nikmat terbesar pada manusia yang diberikan oleh Allah SWT, yakni iman dan sehat. Iman akan meningkat apabila kita bersuci (thaharah) dan melakukan pembersihan bathin dan amal perbuatan kita. Sedangkan kesehatan akan diraih apabila kita menjaga kebersihan fisik (jasmani) dan lingkungan sekitar. Sebagaimana sabda Rasulullah SAW berikut ini, "Dari Ibnu Umar rodhiallahu 'anhu berkata: Rasulullah sholallahu 'alaihi wa sallam memegang pundakku dan bersabda, "Jadilah engkau di dunia ini seperti orang asing atau penyeberang jalan." Ibnu Umar rodhiallahu 'anhu berkata, "Jika kamu berada di sore hari, jangan menunggu pagi hari, dan jika engkau di pagi hari janganlah menunggu sore, manfaatkanlah masa sehat. Sebelum datang masa sakitmu dan saat hidupmu sebelum datang kematianmu” (HR Bukhari).

Dan kemudian ditambahkan sabda Rasulullah SAW, "Ada dua kenikmatan yang membuat banyak orang terpedaya yakni nikmat sehat dan waktu senggang (Artinya, saatsaat sehat dan waktu senggang atau luang orang sering menggunakannya untuk melakukan perbuatan yang sia-sia dan terlarang)" (HR Bukhari).

Media utama untuk membersihkan diri adalah air, namun apabila kita kesulitan untuk mendapatkan air, dapat digunakan media lain seperti tanah, debu, batu, dan lain-lain, sebagaimana firman Allah SWT, 
Hai orang-orang yang beriman, apabila kamu hendak mengerjakan shalat, maka basuhlah mukamu dan tanganmu sampai dengan siku, dan sapulah kepalamu dan (basuh) kakimu sampai dengan kedua mata kaki, dan jika kamu junub maka mandilah, dan jika kamu sakit atau dalam perjalanan atau kembali dari tempat buang air (kakus) atau menyentuh perempuan, lalu kamu tidak memperoleh air, maka bertayammumlah dengan tanah yang baik (bersih); sapulah mukamu dan tanganmu dengan tanah itu. Allah tidak hendak menyulitkan kamu, tetapi Dia hendak membersihkan kamu dan menyempurnakan nikmat-Nya bagimu, supaya kamu bersyukur" (QS al Maidah: 6).

Bersuci (thaharah) dalam ilmu fikih termasuk syarat wajib melakukan ibadah shalat. Belum memenuhi persyaratan sah dalam melakukan shalat, apabila syarat kesucian dan kebersihan tidak terlaksana. Perilaku bersih dan suci merupakan ciri orang yang beriman, sebagaimana Rasulullah SAW bersabda, Dari Abu Malik Al-Harits bin Ashim Al-Asy'ari radhiyallaahu 'anhu, Dia berkata:

Rasulullah sholallahu 'alaihi wa sallam pernah bersabda, "Bersuci adalah separuh dari keimanan, ucapan 'Alhamdulillah' akan memenuhi timbangan, 'subhanalloh walhamdulillah' akan memenuhi ruangan langit dan bumi, sholat adalah cahaya, dan sedekah itu merupakan bukti, kesabaran itu merupakan sinar, dan al Quran itu merupakan hujjah yang akan membela atau menuntutmu. Setiap jiwa manusia melakukan amal untuk menjual dirinya, maka sebagian mereka ada yang membebaskannya (dari siksa Allah) dan sebagian lain ada yang menjerumuskannya (dalam siksa-Nya)" (HR Muslim).

\section{Fiqih Thaharah}

Aktivitas bersuci (thaharah) selalu berhubungan dengan air, dan akan menjadi pertimbangan yang sangat kuat terhadap perancangan dan perencanaan MCK atau toilet yang berlandaskan prinsip islam. Selain itu Kamar Mandi juga harus memenuhi persyaratan arsitektural dan kesehatan (Akmal, 2006: 34). Berikut diuraikan tentang peranan air yang dipakai untuk bersuci,

1. Semua air yang turun dari langit atau yang keluar dari dalam bumi adalah suci dan mensucikan, artinya air tersebut dapat dipakai sebagai media menghilangkan kotoran atau najis (Azhim, 2007: 11). Sebagaimana firman Allah SWT, "Dan Kami menurunkan dari langit air yang amat suci" (QS al Furqaan: 48).

Dan sabda Rasulullah SAW tentang air laut, "Ia (laut itu) suci airnya dan halal bangkainya." (HR Ibnu Majah)

2. Air tersebut tetap suci meskipun bercampur dengan sesuatu yang suci pula selama tidak keluar dari persyaratan batas kesuciannya yang mutlak, yakni perubahan kualitas bau, rasa, dan warna yang menjadi lebih kotor atau jorok, karena ada sabda Rasulullah saw kepada sekelompok wanita yang akan memandikan puterinya, 
"Mandikanlah dia tiga kali, atau lima kali atau lebih dari itu kalau kamu berpendapat begitu dengan air dan daun bidara. Dan pada kali yang terakhir berilah kapur barus atau sedikit kapur barus" (HR Muslim).

Jangan terburu-buru menyimpulkan dan memutuskan bahwa air tersebut najis apabila tercelup benda lain yang najis, apabila tidak terjadi perubahan pada ciri fisiknya. Hal ini didasarkan pada hadits Abu Sa'id, ia berkata:

Ada seorang sahabat yang bertanya Ya Rasulullah, bolehkah kami berwudhu dengan air sumur budha'ah? yaitu sebuah sumur yang darah haidh, daging anjing, dan barang yang bau busuk dibuang ke dalamnya. Maka jawab Beliau, air itu suci, tidak bisa dinajiskan oleh sesuatu pun" (Takhrij hadits ini persis dengan takhrij tentang sumur budha'ah sebelumnya).

3. Kategori suci untuk air adalah terjadi tidaknya perubahan fisik dan mutu air tersebut, baik dari warna, bau, atau rasa. Apabila terjadi perubahan mutu yang lebih rendah atau kotor pada air tersebut maka air tersebut termasuk tidak suci dan tidak dapat mensucikan. Hal ini didasarkan ada hadits berikut ini, Dari Abu Umamah al-Bahili berkata, Rasulullah SAW bersabda, "Sesungguhnya air itu tidak dinajiskan oleh sesuatu kecuali jika berubah baunya, rasanya, dan warnanya."

Para ulama bersepakat bahwa air yang sedikit atau yang banyak apabila tercampuri sesuatu yang najis, lalu najis itu merubah rasa, warna, atau bau maka air tersebut termasuk najis. Jadi dalil najisnya air yang tercampur dengan najis lalu berubah salah satu sifatnya adalah ijma' buka tambahan itu (pengecualian). Secara kimiawi, air yang terlarut benda lain, susunan senyawa air tersebut akan mengalami perubahan, dan dengan alat uji atau tes yang serba canggih, perubahan air baik dari bau, rasa, dan warna akan segera diketahui. Namun parameter perubahan yang seperti apa yang disahkan menurut syar' $i$, apabila air tercelup di dalamnya oleh benda lain masih dikatakan suci. Maksud dari tidak terjadi perubahan disini adalah batas toleransi perubahan yang terjadi komposisi di dalam air tersebut masih memenuhi syarat batas minimal air tersebut dikatakan layak sebagai media bersuci.

4. Rasulullah SAW pernah menjabarkan mengenai volume air yang memenuhi persyaratan suci dan terbebas dari najis atau kotoran, sebagaimana Abdullah bin Umar berkata, Rasulullah SAW bersabda, "Apabila air itu mencapai dua qulla, maka ia tidak menanggung kotoran.” Dalam lafazh lain, “tidak najis”. Hadits ini diriwayatkan oleh Ibnu Khuzaimah, al-Hakim, dan Ibnu Hibban. 
Qulla adalah bejana orang arab seperti tong besar. Qulla disini adalah qulla Hajar karena dengannya Nabi SAW sering menakar. Hadits di atas memberikan ketentuan air sedikit dan air yang banyak. Yang pertama kurang dari dua qulla, yang kedua adalah dua qulla atau lebih dari qulla Hajar. Jika air kurang dari dua qulla lalu tercampur oleh najis, maka najis ini mempengaruhinya. Adapun jika air itu dua qulla atau lebih lalu ia terkena najis, maka air tersebut tidak menjadi najis karena ia tidak menanggungnya atau tidak terpengaruh. Angka dua qulla ini sebagai angka minimal volume air tersebut dapat dipakai untuk bersuci. Mengenai air yang memenuhi syarat untuk bersuci atau wudhu harus memenuhi ketentuan-ketentuan berikut: (1) Suci dari najis dan mensucikan (tohir mutohhir, belum pernah dipakai untuk bersuci sebelumnya. Air yang sudah terpakai dan kurang dari dua qulla yang habis dipakai berwudhu tidak sah digunakan berwudhu lagi, walaupun suci, karena ia suci namun tidak mensucikan. (2) Kalau airnya tidak mengalir, memang harus banyak. Ia terhitung banyak jika memenuhi minimal 2 qulla. Jika dihitung dengan satuan liter 2 qulla berisi sekitar 500 ritl Irak, sedangkan dalam satuan liter ada beberapa pendapat: (a) menurut al Nawawi, 2 qulla itu sama dengan 174,580 liter ; (b) menurut al Rafi'i sama dengan 176,245 liter; (c) dan menurut Imam al Bagdadi, 2 qulla sama dengan 245,325 liter. (3) Air yang mutlak, maksudnya tidak boleh dengan air yang sedikit (kurang dari dua qulla), karena air yang sedikit akan menjadi musta'mal, diantaranya karena tertetesi atau terciprati air yang kita pakai wudhu. Air yang banyak (dua qulla) baru tidak bisa digunakan bersuci (berwudhu), jika sifat-sifat aslinya (kemutlakannya) berubah, baik oleh najis atau barang suci lainnya. Sifat-sifat asli yang dimaksud adalah warna, bau dan rasa. Standar minimal volume ini dipakai pertimbangan dalam merancang bak mandi, di mana minimal ukuran bak mandi yang memenuhi persyaratan suci dan tidak najis adalah panjang $x$ lebar $x$ tinggi yang berukuran $60 \mathrm{~cm} \times 60 \mathrm{~cm} \times 70 \mathrm{~cm}=252.000 \mathrm{~cm}^{2}$ atau 252 liter. Takaran ini di atas batas minimal pendapat Imam al Bagdadi di mana 2 qulla sama dengan 245,325 liter. Aplikasi ukuran standar minimal untuk bak mandi ini seperti ditunjukkan pada Gambar 5. 


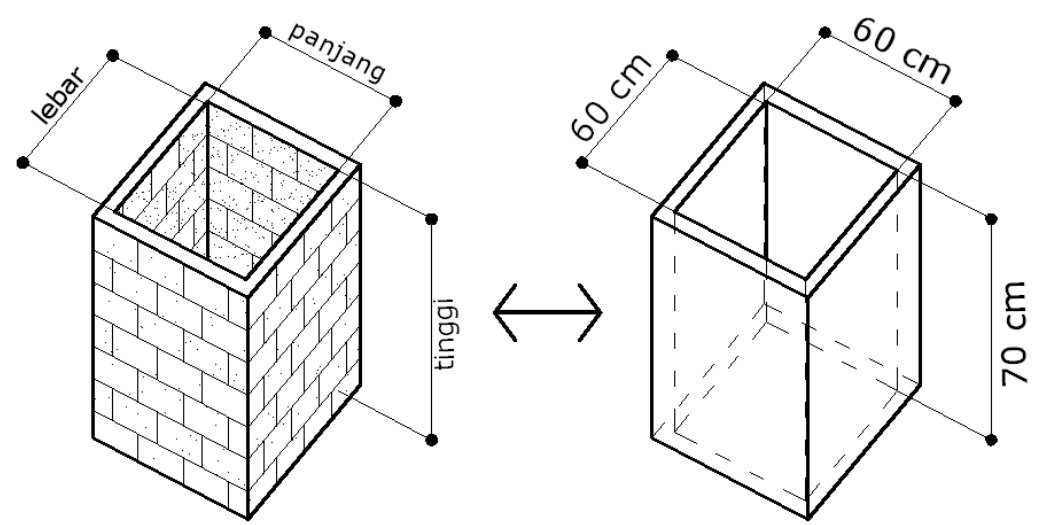

Gambar 5. Ukuran standar minimal bak mandi untuk bersuci

Bentuk bak mandi pada Gambar 5. adalah persegi (balok), sedangkan untuk bak mandi yang berbentuk silinder (tabung) atau bentuk-bentuk lainnya dipakai ukuran yang berbeda dan disesuaikan dengan rumus mencari volume bentuk geometri bak mandi yang dipakai, dengan tetap mengacu bahwa volume yang boleh dipakai untuk bersuci minimal sebanyak dua qulla atau 245,325 liter.

5. Dari Abu Hurairah berkata, Rasulullah SAW bersabda,

"Janganlah salah seorang di antara kamu mandi di air yang tenang sementara dia junub” (Riwayat Muslim).

Dalam riwayat al Bukhori,

"Janganlah salah seorang di antara kamu kencing di air yang tenang tidak mengalir, kemudian mandi di dalamnya."

Dari dua hadits di atas, dapat diterangkan bahwa untuk lafazh riwayat Muslim menunjukkan larangan mandi bagi orang junub di dalam air yang tenang secara mutlak, baik air itu sedikit ataupun banyak, baik sebelumnya didahului kencing di dalamnya atau tidak (al Hamd, 2005: 9). Lafazh riwayat al Bukhori menunjukkan larangan menggabungkan antara kencing dan mandi di air yang tenang. Dari ketentuan ini arsitek perlu merancang agar di dalam Kamar Mandi tidak terjadi genangan air buangan, diupayakan air tidak terhenti. Solusi pemecahaannya adalah merancang kemiringan lantai agar air buangan cepat keluar menuju saluran pembuangan. Untuk menentukan sudut kemiringan lantai Kamar Mandi dipakai metode perhitungan dengan mempertimbangkan volume pemakaian air. Berikut contoh persoalan bagaimana cara menentukan sudut kemiringan lantai KM/WC. 
Contoh persoalan: Terdapat Kamar Mandi dan WC seperti pada Gambar 6. di bawah dengan ukuran $120 \mathrm{~cm}$ x $170 \mathrm{~cm}$, area lantai pembuangan air seluas $9 \mathrm{~cm}^{2} \times 12 \mathrm{~cm}^{2}=$ $108 \mathrm{~cm}^{2}$. Berdasarkan volume penggunaan air rata-rata di dalam Kamar Mandi sebuah rumah tangga adalah debit 2,65 liter/detik (Soufyan \& Morimura,1999). Dicari berapa sudut kemiringan lantai agar air yang dipakai mandi atau buang hajat segera terbuang dan tidak menimbulkan genangan (Pengaturan kemiringan lantai juga mempertimbangkan kenyamanan pengguna)?
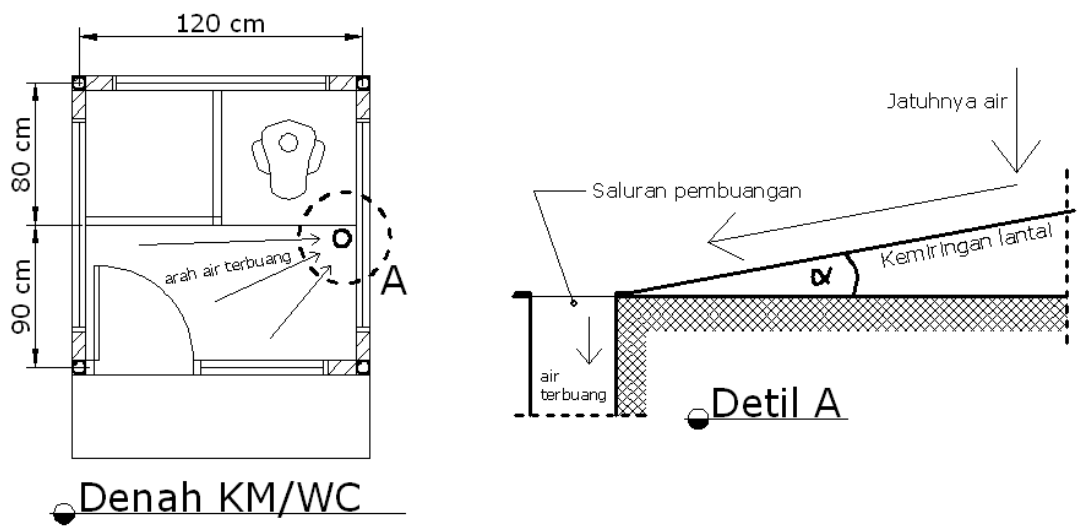

Gambar 6. Denah dan potongan detil kemiringan lantai KM/WC

Penyelesaian!

a. Kita ketahui bahwa volume air ketika diguyurkan dari gayung ke badan $\left(\mathrm{V}_{1}\right)$ sama dengan air yang tumpah mengalir di lantai dan menuju pembuangan $\left(\mathrm{V}_{2}\right)$, berarti $\mathrm{V}_{1}=\mathrm{V}_{2}$.

- Rumus volume $=$ debit air $\times$ waktu ------ $\mathrm{V}=\mathrm{Q} \times \mathrm{t}$

- Sesuai hukum percepatan gravitasi (g) bahwa $S=$ g.t $t^{2}$

- dimana $\mathrm{S}=\mathrm{jarak}, \mathrm{g}=$ percepatan akibat gravitasi sebesar $9,8 \mathrm{~m} / \mathrm{detik}^{2}$, dan $\mathrm{t}=$ waktu .

- Sementara tinggi rata-rata orang Indonesia adalah $150 \mathrm{~cm}=1,5 \mathrm{~m}$, maka: $\mathrm{S}=$ g.t $\mathrm{t}^{2}$ ----- $1,5 \mathrm{~m}=9,8 \cdot \mathrm{t}^{2}$---- $\mathrm{t}=\sqrt{\frac{1,5}{9,8}}=0,391$ detik. Jadi air akan sampai ke lantai setelah 0,391 dari turunnya air dari gayung membasahi tubuh. Pada $t=0,391$ detik, volume air yang ada $=2,65$ liter/detik x 0,391 detik $=1,036$ liter

- Percepatan merupakan besaran yang memiliki arah (vektor), untuk menetapkan kemiringan lantai dapat dicari dengan ilmu ukur sudut (Gambar 7). 


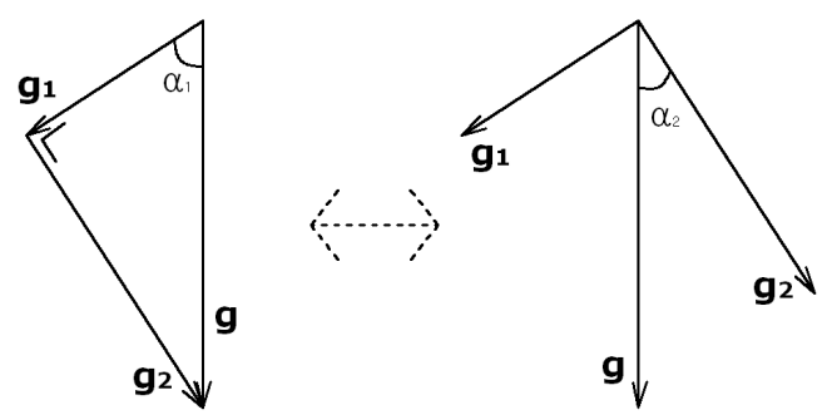

Gambar 7. Prinsip dasar ilmu ukur segitiga dalam vektor

Dari Gambar 7, didapatkan bahwa $\mathrm{g}_{1}=\mathrm{g} \cdot \cos \alpha_{1}$, dan $\mathrm{g}_{2}=\mathrm{g} \cos \alpha_{2}$, sehingga dari rumus ini didapatkan percepatan seperti pada item berikut.

b. Kita pakai sudut kemiringan $\alpha=5^{\circ}$, dengan hukum segitiga maka $\alpha_{1}=85^{\circ}$. Dapat dicari percepatan gravitasi $\left(g_{1}\right): g_{1}=$ g. $\cos \alpha_{1}=9,8 \cdot \cos 85^{\circ}=9,8 \cdot 0,0872=0,854 \mathrm{~m} / \mathrm{detik}^{2}$ Jarak terjauh dari Kamar Mandi atau WC (Gambar 6) adalah $120 \mathrm{~cm}=1,2 \mathrm{~m}$. Maka waktu yang dibutuhkan untuk sampai di lubang pembuangan adalah $S=g_{1} \cdot \mathrm{t}^{2}$----$1,2 \mathrm{~m}=0,854 \cdot \mathrm{t}^{2}$----- $\mathrm{t}=\sqrt{\frac{1,2 m}{0,854 m / \operatorname{det}^{2}}}=1,185 \mathrm{detik}$

$\mathrm{V}_{1}=\mathrm{V}_{2}$---- $\mathrm{V}_{1}=1,036 \mathrm{ltr}---\mathrm{V}_{1}=\mathrm{Q}_{1} . \mathrm{t}=1,036 \mathrm{ltr}---\mathrm{Q}_{1} .1,185=1,036$ liter --- $\mathrm{Q}_{1}=$ 0,874 liter/detik. Sementara debit air yang datang dalam 1 detik adalah 2,65 liter berarti dibutuhkan waktu $=\frac{2,65}{0,874}=3,03$ detik dengan genangan air yang dapat ditimbulkan $=\frac{2,65 \text { liter }\left(\mathrm{dm}^{3}\right)}{9 \mathrm{dm} \times 12 \mathrm{dm}}=0,025 \mathrm{dm}=0,25 \mathrm{~cm}$. Angka genangan di atas normal dan wajar, sebab interval waktu orang mandi ambil air gayung per gayung \pm 3 detik, sehingga genangan $0,25 \mathrm{~cm}$ akan hilang dengan jeda waktu \pm 3 detik.

c. Mencari diameter $(\varnothing)$ lubang saluran pembuangan adalah dengan Tabel Penentuan Pipa Plumbing (Tanggoro, 2000: 8). Fasilitas Kamar Mandi atau WC. Apabila kemiringan lantai dipakai $\alpha=5^{\circ}$, debit aliran air buangan $=0,874$ liter/detik $=$ 52,44 liter/menit. Maka berdasarkan tabel, dipakai lubang buangan diameter $(\varnothing)=$ $1 \frac{1}{4} "=3,715 \mathrm{~cm}$ dengan kapasitas buang 60 liter/menit.

Dari dua hasil perhitungan tersebut, dapat dilakukan iterasi hasil desain kemiringan lantai yang optimal dan dikehendaki, asalkan lantai menghasilkan genangan air yang wajar dan normal. Jangan sampai kemiringan lantai tidak mampu meneruskan air buangan yang berakibat air tergenang dan terjadi banjir di dalam 
Kamar Mandi atau WC. Kasus semacam ini sering terjadi, sehingga berdampak kurang nyaman dan terganggunya aktivitas di dalam Kamar Mandi. Kasus demikian juga melanggar sunnah Rasul, bahwa kita dilarang kencing dan mandi di air yang tidak mengalir, oleh karena itu analisis semacam ini sangat diperlukan agar tidak terjadi kesalahan perancangan.

6. Larangan baik laki-laki maupun perempuan untuk bersuci dengan menggunakan air sisa yang telah digunakan orang, sebagaimana terdapat keterangan dari seorang lakilaki sahabat Nabi SAW berkata, "Rasulullah SAW melarang wanita mandi dari sisa orang laki-laki, atau orang laki-laki mandi dari sisa wanita. Hendaknya keduanya mengambil air dari gayung" (riwayat Abu Daud dan an-Nasa'i).

Laki-laki yang tidak diketahui identitasnya dalam hadits ini, konon adalah al Hakam bin Amru. Ada yang mengatakan Abdullah bin Mughaffal (al Hamd, 2005: 11). Dan banyak intepretasi yang lain siapa yang dimaksud seseorang dalam hadits ini. Namun secara nyata bahwa hadits ini menunjukkan larangan laki-laki mandi dari air sisa mandi wanita, begitu juga sebaliknya. Sisa di sini maksudnya adalah sisa air di dalam gayung, jadi hendaknya kita mengambil air baru dari suatu bejana atau bak mandi dengan gayung.

7. Kita dilarang mengganggu orang dalam buang hajat misalkan pada saat orang sedang kencing kita memotong hajat tersebut atau menyuruh berhenti, padahal masih belum selesai. Sebagaimana dijelaskan dalam hadits berikut ini,

Dari Anas bin Malik ra berkata, "Telah datang seorang Badui lalu dia kencing di sudut masjid, lalu orang-orang menghardiknya, tetapi Nabi SAW melarang mereka. Ketika dia telah menyelesaikan kencingnya Nabi saw memerintahkan agar kencingnya disiram dengan setimba air"(Muttafaq Alaihi).

At Tirmidzi meriwayatkan hadits ini dengan tambahan bahwa orang Badui ini datang ke masjid dan shalat, Tidak berapa lama kemudian dia kencing di masjid. Ini menunjukkan bahwa orang Badui tersebut adalah muslim. Ketika dia mulai kencing, para sahabat menghardiknya dengan keras. Lalu Rasulullah SAW melarang mereka memutus kencingnya. Beliau bersabda kepada mereka, “ Biarkan dia, dan siramkanlah setimba air." Kemudian beliau menambahkan, "Sesungguhnya kalian diutus untuk mempermudah, dan tidak diutus untuk mempersulit."

Dan dalam riwayat lain disebutkan bahwa Nabi memanggilnya manakala dia telah menyelesaikan kencingnya, dan bersabda kepadanya, "Sesungguhnya masjid itu tidak 
boleh dikencingi dan dikotori, ia hanya untuk dzikrullah aza wajalla, shalat, dan membaca al Quran."

Dari beberapa keterangan di atas, dapat disimpulkan bahwa kencing manusia merupakan benda najis, apabila tanah terkena najis, maka ia disucikan dengan air seperti benda-benda yang terkena najis, air yang disiramkan mensucikan tanah yang lunak ataupun yang keras, kewajiban menghormati masjid, mengajar dengan lemah lembut kepada orang bodoh, kebaikan akhlak, kelembutan, dan kasih sayang Nabi SAW, dan mencegah kerugian paling besar dengan melakukan kerugian yang lebih rendah.

\section{Pemisahan Tatanan Kamar Mandi, WC, dan Tempat Cuci Dari Najis}

Dalam perancangan Kamar Mandi atau WC, arsitek muslim harus mampu memilah ruang-ruang tempat bersuci berdasarkan tingkatan benda najis yang berada di tempat tersebut. Dari tingkatan najis tempatnya dapat dibuat konsep pemilahan ruang sebagaimana pada bagan berikut,

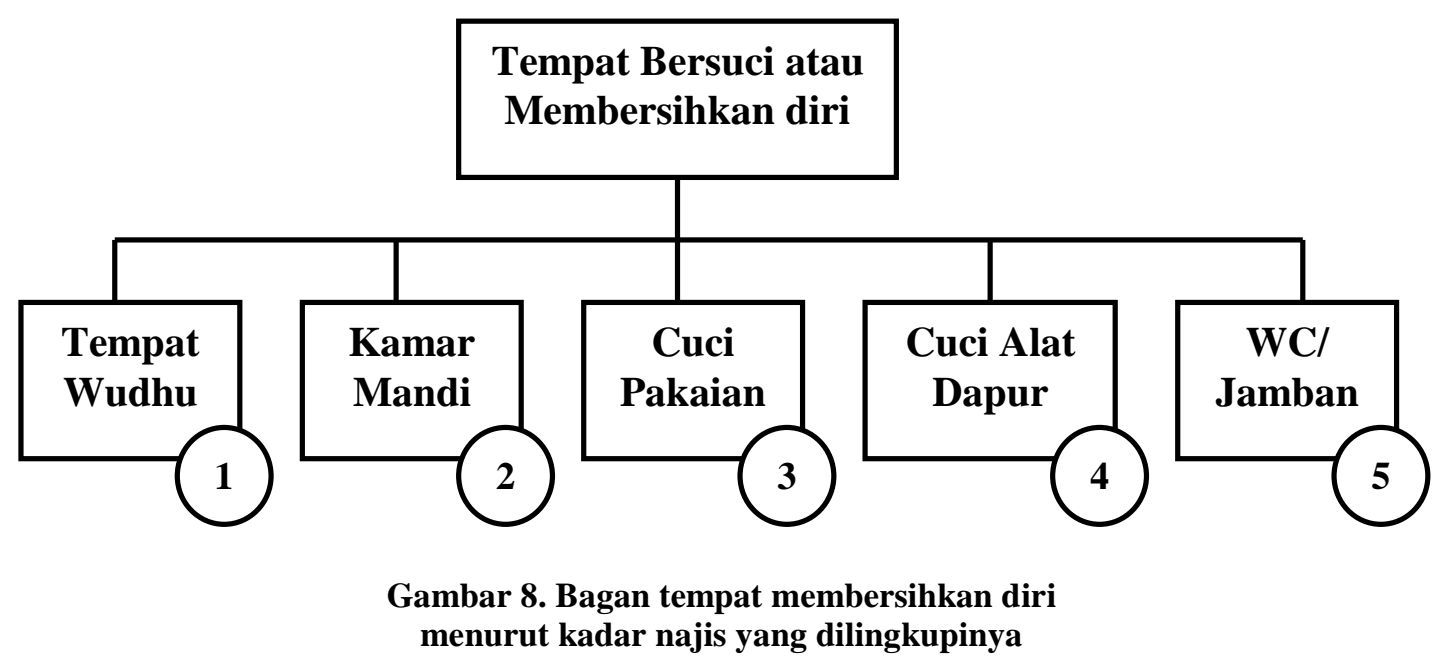

Menurut Gambar 8. di atas dapat dibedakan tempat membersihkan diri baik thaharah, instinja' dan mencuci yang ideal menurut tingkatan najis yang diterimanya sebagai berikut,

1. Tempat wudhu, merupakan tempat mengambil air wudhu untuk keperluan shalat, baca al Quran, atau kegiatan ibadah lain, yang tidak memerlukan ruang (space) yang terlalu luas, minimal luas (area) $\pm 0,81 \mathrm{~m}^{2}(0,9 \times 0,9)$ tiap orang. Tempat ini harus terjaga kesucian dan terbebas dari najis.

2. Kamar Mandi, adalah tempat mandi baik mandi sekedar membersihkan diri (rutinitas), mandi sunnah, maupun mandi besar (janabat). Ukuran luas Kamar Mandi disesuaikan dengan dimensi kenyamanan manusia (ergonomi manusia). Hal ini sudah tercantum 
dalam standar di berbagai negara maupun standar internasional. Untuk menghindari melubernya air dari dalam Kamar Mandi atau WC menuju ruang-ruang yang lain maka perlu pengaturan ketinggian lantai (peil) Kamar Mandi atau WC (SNI 03-2399-2002). Ketinggian Kamar Mandi atau WC dibuat lebih rendah $\pm 3 \mathrm{~cm}$ terhadap lantai di luarnya, agar air tidak sampai meluber (mengalir) keluar, seperti pada Gambar $9-11$.

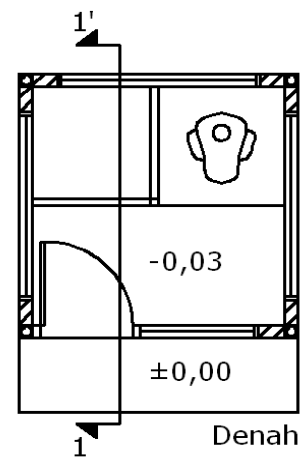

Gambar 9. Peil Lantai KM/WC

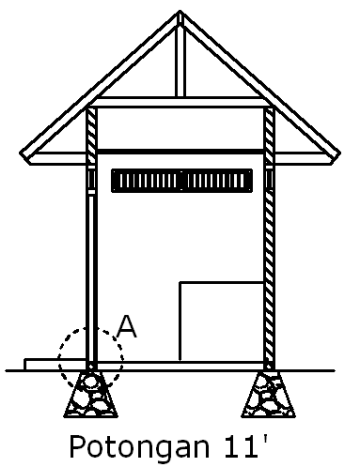

Gambar 10. Potongan KM/WC

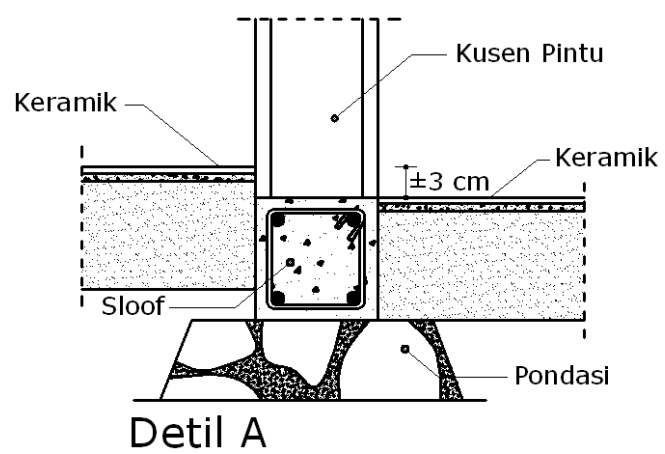

Gambar 11. Detil A (Detil Perbedaan Peil Lantai KM/WC)

3. Tempat cuci pakaian, adalah tempat untuk mencuci pakaian sehari-hari, atau benda yang terbuat dari bahan tekstil (kain), dan sejenisnya. Biasanya untuk tempat tinggal, tempat cuci didekatkan dengan Kamar Mandi atau WC. Proses pengaturan dan penataan tempat cuci pakaian adalah dengan mempertimbangkan luas (area) untuk mencuci karena area ini diliputi oleh peralatan dan perlengkapan mencuci.

4. Tempat cuci peralatan dapur, merupakan tempat atau ruang untuk mencuci peralatan dapur dan semacamnya. Biasanya tempat ini berada satu ruang dengan dapur atau menjadi satu dengan tempat cuci pakaian. Untuk bangunan modern toilet atau WC, tempat cuci pakaian dan peralatan dapur berada di dalam ruangan bangunan. Untuk rumah daerah pelosok atau pedesaan, tata letak dapur berada dalam ruangan bangunan, sementara tempat cuci pakaian dan peralatan dapur berada di luar ruangan.

5. Water Closet (WC), nama lain adalah kakus (jamban) adalah tempat membuang hajat atau buang air baik besar maupun kecil. Tempat ini merupakan tempat yang paling banyak ditempati kotoran atau barang najis. Jadi disarankan tidak berwudhu di tempat ini, kecuali kebersihannya terjamin. Saran yang lain hendaknya dipisahkan dengan Kamar Mandi, dengan pertimbangan selain membagi fungsi dan tingkat kepentingan juga membagi kadar najis yang diterima setiap tempat, mengingat Kamar Mandi juga dipakai untuk mandi besar (janabat) dan wudhu. Namun apabila mengalami kesulitan dalam menata dan memilah ruangan tersebut, dengan pertimbangan lahan yang sempit diperbolehkan dijadikan satu tempat. 
Dari penggolongan di atas dapat dibuat item perancangan Kamar Mandi, WC, tempat cuci, dan wudhu. Kamar Mandi atau WC dirancang dan ditata berdasarkan kadar najis yang dilingkupi setiap tempat. Konsep penataan Kamar Mandi, jamban dan semacamnya secara tradisional masih cukup layak dijadikan dasar dan masukan bagi perancangan Kamar mandi atau WC yang islami dan sehat. Konsep penataan secara tradisional, Kamar Mandi atau WC, tempat cuci pakaian dan alat dapur, dan sumur diletakkan di bagian belakang dan di luar bangunan, dan antara Kamar Mandi dan WC dibuat terpisah. Sementara sumber air yang digunakan adalah sumur. Penataan seperti ini sangat unik dan merupakan corak khas arsitektur tradisional Indonesia. Seperti terlihat pada Gambar 12 - 14 di bawah ini:

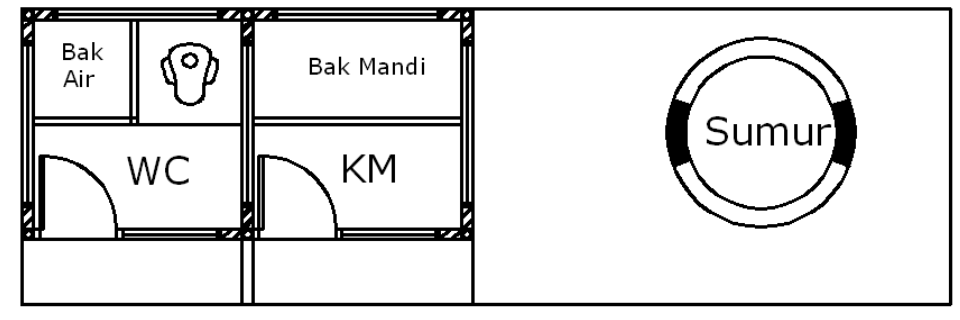

Denah

Gambar 12. Denah KM/WC, tempat cuci, dan sumur yang dipisah

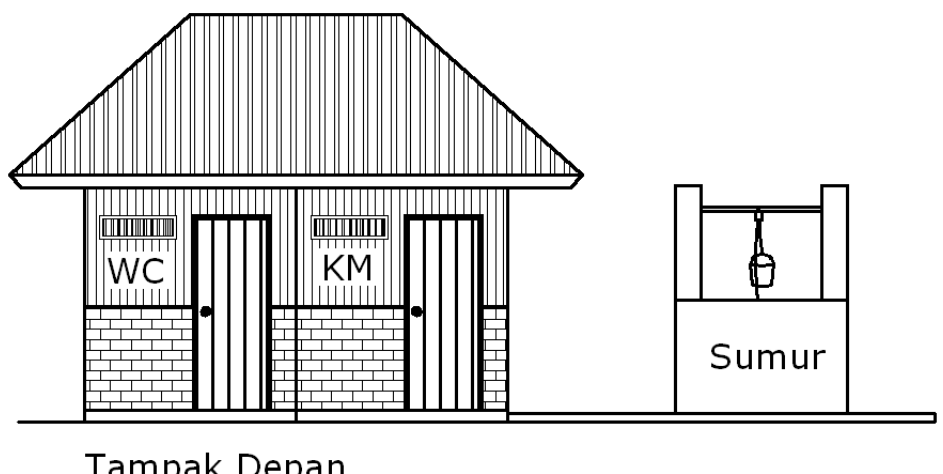

Tampak Depan

Gambar 13. Tampak depan KM/WC, tempat cuci, dan sumur yang dipisah 


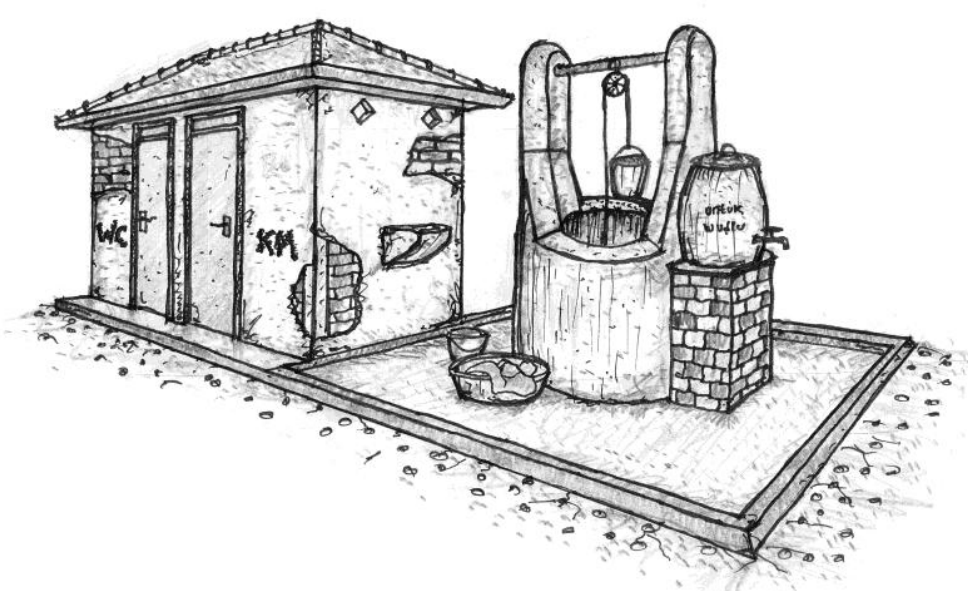

Gambar 14. Pemisahan KM/WC, tempat cuci, sumur, dan tempat wudhu pada rumah tinggal pedesaan

Penataan fasilitas untuk membersihkan diri secara tradisional selain kita temui di pedesaan, beberapa rumah tinggal di daerah kota juga ada yang masih menerapkan konsep demikian (Gambar 15). Konsep seperti ini sebenarnya memiliki kelebihan baik dari tinjauan agama islam maupun kesehatan. Penataan dengan model seperti ini memiliki kekurangan, antara lain dalam pencapaian (akses) terasa sulit karena letaknya di luar bangunan, apalagi pada saat hujan atau tengah malam jelas akan terganggu baik kenyamanan dan keamanannya. Selain itu faktor lahan dan ruang yang perlu disediakan juga diperhitungkan, karena konsep penataan semacam ini akan membutuhkan ruang dan lahan yang lebih luas. Berbeda halnya jika Kamar Mandi atau WC diletakkan dalam bangunan, akses mudah dicapai, namun demikian dalam rumah akan basah atau becek karena air, Kamar Mandi atau WC tidak mendapatkan udara segar atau sirkulasi udara kurang lancar. Jadi solusi terbaik adalah penggabungan kedua aspek perancangan tersebut agar didapatkan hasil rancangan yang benar-benar islami dan memenuhi standar kesehatan.

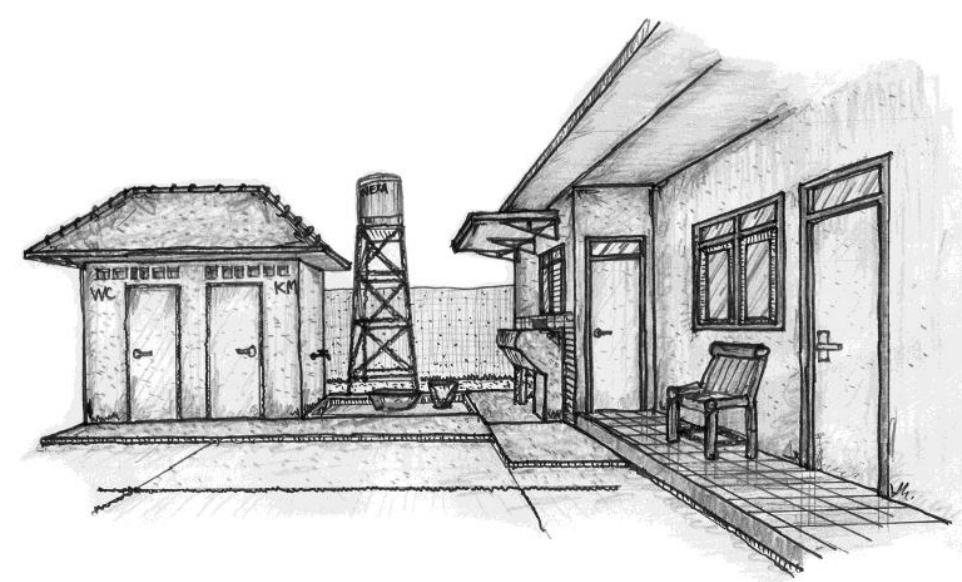

Gambar 15. Pemisahan kamar mandi, WC, dan tempat cuci 


\section{Simpulan}

Kamar Mandi atau WC dan tempat sejenisnya merupakan tempat penting dalam tatanan bangunan rumah tinggal. Tempat ini berfungsi utama sebagai tempat membersihkan diri, buang kotoran, dan bersuci (thaharah). Bersuci menjadi prasyarat utama yang menentukan sah tidaknya ibadah manusia terhadap Tuhannya, seperti shalat, membaca dan mengkaji al Quran, dzikir, dan lain-lain. Bahkan tidak hanya pada saat hendak melakukan ibadah shalat atau ngaji saja, di setiap saat dan kesempatan kita dianjurkan menjaga kesucian dan kebersihan baik lahir maupun batin.

Prinsip-prinsip hukum dan ilmu fikih bersuci dapat dijadikan acuan dan landasan dalam perancangan Kamar Mandi yang islami, artinya Kamar Mandi tersebut menunjang akvititas bersuci, sebagai bentuk amal ibadah kita sehari-hari. Beberapa aspek rancangan yang perlu diperhatikan sebisa mungkin ada pemisahan tempat bersuci baik Kamar Mandi, WC, tempat wudhu, dan tempat pencucian barang. Hal ini dimaksudkan untuk memisahkan najis di setiap tempat. Ukuran bak mandi juga diatur dengan volume tampung minimal air sebanyak 2 qulla atau 245,325 liter, sehingga bisa dikategorikan air bebas najis, asalkan tidak berubah sifat fisis dan kimianya. Kemiringan dan ketinggian lantai juga diperhitungkan agar tidak timbul genangan air dan mengalirkan najis ke ruangan lain. Dengan penerapan rancangan prinsip-prinsip islami seperti inilah diharapkan Kamar Mandi atau WC yang kita miliki mendukung ibadah yang dilakukan dan menjadikan diri kita menjadi insan yang suci lahir dan bathin.

\section{Daftar Pustaka}

Anonim. SNI 03-2399-2002 tentang Tata Cara Perencanaan Bangunan MCK Umum. Jakarta: Departeman Kimpraswil.

Akmal, Imelda. 2006. Kamar Mandi. Jakarta: Gramedia Pustaka Utama.

Al-Hamd, Abdul Qadir Syaibah. 2005. Fiqhul Islam: Syarah Bulugul Maram. Jakarta: Darul Haq.

Ambeno, Prima Nataniel. 2010. Desain Sarana MCK untuk Daerah Korban Bencana. Surabaya : Jurusan Desain Produk Industri Institut Teknologi Sepuluh Nopember. 
Azhim, Abdul bin Badawi Al-Khalafi. 2007. Al-Wajiz: Ensiklopedi Fiqih Islam dalam alQuran dan As-Sunnah As Shahihah. Jakarta: Pustaka as-Sunnah.

Hazm, Abu Muhammad Ali bin Ahmad bin Sa'id. 2007. Al Muhalla, penerjemah Ahmad Rijali Kadir. Jakarta: Pustaka Azzam.

Hermawan. 2010. Desain Closet Jongkok Yang Memperhatikan Kebutuhan Konsumen dan Dilandasi Nilai - Nilai Islam Dalam Pemakaiannya. Surabaya : Jurusan Desain Produk Industri Institut Teknologi Sepuluh Nopember.

Murtini, Titien Woro, dkk. 1995. Kajian Perancangan Kamar Mandi Rumah Tinggal. Semarang : Jurusan Teknik Arsitektur Universitas Diponegoro.

Tanggoro, Dwi. 2000. Utilitas Bangunan. Jakarta: Penerbit Universitas Indonesia.

Taufik, M.Tata. 2007. Mengkomunikasikan Ajaran Islam Sebagai Inspirasi Perilaku Hidup Sehat. Seminar Nasional "Penguatan Peran Ulama Dalam Penanggulangan HIV/AIDS dan Penyalahgunaan Narkoba". Lembah Ciremai Kuningan, Jakarta. 